\title{
In vitro study of soil arsenic release by human gut microbiota and its intestinal absorption by Caco-2 cells
}

\author{
Naiyi Yin ${ }^{\text {a, c }}$, Xiaolin Cai ${ }^{\text {a, c }}$, Huili Du ${ }^{\text {a, c }}$, Zhennan Zhang ${ }^{\text {a, c }}$, Zejiao Li ${ }^{\text {a, c }}$, Xiaochen Chen ${ }^{b}$, \\ Guoxin Sun ${ }^{\mathrm{c}}$, Yanshan Cui ${ }^{\mathrm{a}, \mathrm{c}, *}$ \\ ${ }^{a}$ College of Resources and Environment, University of Chinese Academy of Sciences, Beijing, 101408, People's Republic of China \\ ${ }^{\mathrm{b}}$ College of Environment and Resources, Fuzhou University, Fujian, 350108, People's Republic of China \\ ${ }^{\mathrm{c}}$ Research Center for Eco-Environmental Sciences, Chinese Academy of Sciences, Beijing, 100085, People's Republic of China
}

\section{H I G H L I G H T S}

- Soil As release $\left(3.7-581.2 \mathrm{mg} \mathrm{kg}^{-1}\right)$ was observed in the colon.

- $44.2-97.6 \%$ of arsenite generated was in the soil solid phase.

- Different degree of cellular absorption of soil As metabolites was observed.

- Arsenic in colon digests was transformed more quickly than that in soil solid phase.

- Gut microbiota can directly release soil arsenic, particularly As-bearing amorphous $\mathrm{Fe} / \mathrm{Al}$-oxides.

\section{A R T I C L E I N F O}

\section{Article history:}

Received 12 August 2016

Received in revised form

20 October 2016

Accepted 24 October 2016

Available online 27 October 2016

Handling editor: A. Gies

\section{Keywords:}

Arsenic

Speciation

Gut microbiota

Caco-2 cell

Soil

\section{G R A P H I C A L A B S T R A C T}

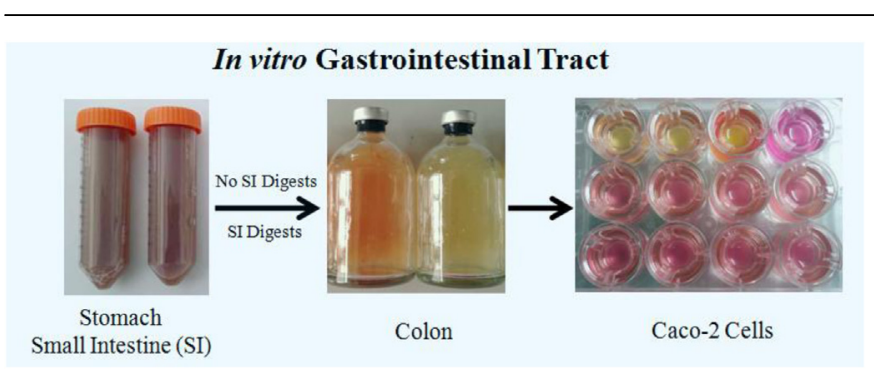

\section{A B S T R A C T}

Arsenic (As) speciation is essential in assessing health risks from As-contaminated soil. Release of soilbound arsenic, As transformation by human gut microbiota, and the subsequent intestinal absorption of soil As metabolites were evaluated. A colon microbial community in a dynamic human gut model and the intestinal epithelial cell line Caco-2 were cultured. Arsenic speciation analysis and absorption of different As species were undertaken. In this study, soil As release (3.7-581.2 $\mathrm{mg} \mathrm{kg}^{-1}$ ) was observed in the colon. Arsenic in the colon digests was transformed more quickly than that in the soil solid phase. Xray absorption near-edge spectroscopy (XANES) analysis showed that $44.2-97.6 \%$ of arsenite [As(III)] generated due to arsenate $[\mathrm{As}(\mathrm{V})]$ reduction was in the soil solid phase after the colon phase. We observed a high degree of cellular absorption of soil As metabolites, exhibiting that the intestinal absorption of monomethylarsonic acid and $\mathrm{As}$ (III) (33.6\% and 30.2\% resp.) was slightly higher than that of dimethylarsinic acid and $\mathrm{As}(\mathrm{V})$ (25.1\% and $21.7 \%$ resp.). Our findings demonstrate that human gut microbiota can directly release soil-bound arsenic, particularly As-bearing amorphous $\mathrm{Fe} / \mathrm{Al}$-oxides. Determining As transformation and intestinal absorption simultaneously will result in an accurate risk assessment of human health with soil As exposures.

(c) 2016 Elsevier Ltd. All rights reserved.

\footnotetext{
* Corresponding author.

E-mail address: cuiyanshan@ucas.ac.cn (Y. Cui).
}

\section{Introduction}

Arsenic (As), a ubiquitous toxic contaminant, is extensively distributed in the soil environment (Bhattacharya et al., 2007). 
Chronic exposure to soil As is associated with serious risks to human health because As is regarded as a class 1 carcinogen (Ljung et al., 2006). Inadvertent oral ingestion of As-contaminated soil and dust has been considered an important exposure pathway, especially through outdoor hand-to-mouth behavior by children (Bradham et al., 2011). Generally, most inorganic As (iAs) is rapidly absorbed in the small intestine, so As methylation by intestinal microorganisms is considered to contribute little to methylation in vivo (Vahter, 1983). However, soil/food-bound As can get into the colon, which is inhabited by an abundant microbial community. In an oral exposure, the metabolism of ingested soil As by gut microorganisms has been investigated with in vivo and in vitro experiments (SHIME model, Simulator of Human Intestinal Microbial Ecosystem) (Naranmandura et al., 2007a; Van de Wiele et al., 2010; Yin et al., 2015). Arsenic species detected in the colon, listed in order of decreasing toxicity, are monomethylarsonous acid $\left(\mathrm{MMA}^{\mathrm{III}}\right)$, dimethylarsinous acid $\left(\mathrm{DMA}^{\mathrm{III}}\right)$, arsenite $[\mathrm{As}(\mathrm{III})]$, arsenate $[\mathrm{As}(\mathrm{V})]$, monomethylmonothioarsonic acid (MMMTA $\left.{ }^{\mathrm{V}}\right)$, monomethylarsonic acid $\left(\mathrm{MMA}^{\mathrm{V}}\right)$, and dimethylarsinic acid $\left(\mathrm{DMA}^{\mathrm{V}}\right)$ (Naranmandura et al., 2007b; Van de Wiele et al., 2010). Arsenic transformation and speciation analysis must be considered an essential part of the risk assessment following soil As exposure.

The SHIME model, a thorough in vitro human gastrointestinal simulator, demonstrated that human gut microbiota have high microbial metabolic potency toward soil As (Van de Wiele et al., 2010; Yin et al., 2015). Clearly, human gut microbiota can actively metabolize As through reduction, methylation, and thiolation. Yin et al. (2015) reported the As speciation of residual soils in the colon phase by X-ray absorption near-edge structure (XANES) and found the distribution of $\mathrm{As}(\mathrm{III})$ and $\mathrm{As}(\mathrm{V})$ in the colon digest and soil solid phase, illustrating that large amounts of As(III) (8.5-13.7\% of total As) were adsorbed onto the soil solid phase. Nevertheless, with consideration to absorption in small intestine, confirming whether human gut microbiota in the colon have the potency to induce As release directly from soils and investigating the conceivable mechanism are urgently needed. If confirmed, we can in vitro explore soil As metabolism by human gut microbiota and these data can result in more accurate risk assessment associated with oral exposure to As-contaminated soils.

The development of in vitro research utilizing Caco-2 cell cultures, which simulates the intestinal cell retention and transport process, can offer a more reliable approximation to in vivo conditions in evaluating bioavailability at the intestinal level (Ekmekcioglu, 2002). The intestinal epithelial cell line Caco-2 of human colon carcinoma origin has been successfully used to estimate the bioavailability of some elements (e.g., cadmium, lead, selenium, mercury, arsenic) (Fu and Cui, 2013; Moreda-Pineiro et al., 2011). Researchers have examined cellular retention and intestinal transport with Caco-2 cells from the standard solutions of different As species [e.g., $\mathrm{As}(\mathrm{V}), \mathrm{As}(\mathrm{III}), \mathrm{MMA}^{\mathrm{III}}, \mathrm{MMA}^{\mathrm{V}}, \mathrm{DMA}^{\mathrm{III}}$, $\mathrm{DMA}^{\mathrm{V}}$, MMMTA ${ }^{\mathrm{V}}$ dimethylmonothioarsenate $\left(\mathrm{DMMTA}^{\mathrm{V}}\right)$ ] (Calatayud et al., 2012c; Hinrichsen et al., 2015; Laparra et al., 2005b). These previous data suggest the different methylated arsenicals have a more efficient cellular absorption capacity than iAs, but the pentavalent methylated $\mathrm{As}, \mathrm{MMA}(\mathrm{V})$ and $\mathrm{DMA}(\mathrm{V})$ have a lower absorption than iAs (Calatayud et al., 2010; Juhasz et al., 2006). There are some factors affecting intestinal transport of these As species, including $\mathrm{pH}$, phosphate or other parameters (Calatayud et al., 2010). Combination of the in vitro gastrointestinal methods and Caco-2 cells has been used to simulate digestion and absorption processes of different As species from foods (Alava et al., 2015; Moreda-Pineiro et al., 2011). However, there are no data regarding As intestinal absorption using Caco- 2 cells after in vitro digestion (stomach and small intestine) and the subsequent As transformation by human colon microbiota from As-contaminated soils; accordingly, it was essential and urgent to estimate the absorption of soil As metabolites with different degrees of toxicity.

Therefore, in the present study, the PBET method (gastric and small intestinal phases), combined with the SHIME (colon phase) and Caco-2 cells (intestinal absorption) was used to investigate (1) As speciation and distribution between the colon digest and the soil solid phase, (2) whether and to what extent soil-bound As in the colon can be released by human gut microbiota, and (3) the degree of intestinal absorption of different As species metabolised by human gut microbiota based on Caco- 2 cells.

\section{Materials and methods}

\subsection{Arsenic-contaminated soils}

In this study, four soils collected from mining and farmland locations in China were used, with As concentrations ranging from 15.5 to $3225.6 \mathrm{mg} \mathrm{kg}^{-1}$. All soil samples were air-dried and sieved to a particle size fraction of $<250 \mu \mathrm{m}$ for in vitro studies, which is most likely to stick to the hands of exposed humans (Kelly et al., 2002). Soil physicochemical properties were measured on triplicate samples as described previously (Yin et al., 2015) and listed in Table S1.

Arsenic speciation in soils was examined using As K-edge XANES, which was performed on beamline 1W2B at the Beijing Synchrotron Radiation Facility (BSRF), China. The steps and reference materials have been described in our previous literature (Yin et al., 2015). Data analysis was conducted using Athena (Demeter 0.9.20). Every sample was normalized, and linear combination fitting (LCF) was used to identify As species from reference materials.

Sequential soil As fractionation was determined by Kim et al. (2014), and the following operationally defined As forms were (F1) non-specifically adsorbed, (F2) specifically adsorbed, (F3) amorphous $\mathrm{Fe}$ and $\mathrm{Al}$ oxides, (F4) crystalline $\mathrm{Fe}$ and $\mathrm{Al}$ oxides, and (F5) residual phase. Samples $(0.45 \mu \mathrm{m}$ filter) were analyzed for soluble As by inductively coupled plasma mass spectrometry (ICPMS, 7500a; Agilent, Palo Alto, CA, USA).

\subsection{Dynamic SHIME}

The in vitro colon microbial community utilized in the experiments was cultured and maintained in a modified SHIME described previously (Van de Wiele et al., 2010). SHIME consisted of five compartments simulating the stomach, small intestine, ascending colon, transverse colon and descending colon. Generally, fresh fecal microorganisms were obtained from one volunteer (Sun et al., 2012; Van de Wiele et al., 2010), a 28-year-old Chinese male volunteer with no history of antibiotic treatment in the six months before this study. Briefly, the different colon compartments were inoculated with fresh fecal microorganisms. Feed solution detailed in Yin et al. (2016) was added three times per day to provide digested nutrition for the colon microorganisms. After 3-4 weeks of adaptation, stable microbial communities were obtained in the colon compartments. The distal colon microbial fermentation activity (short chain fatty acid production and ammonium production) and community composition are consistent with that of previous SHIME runs and an in vivo situation (Molly et al., 1994; Yin et al., 2015).

\subsection{Estimation of bioaccessibile As}

The As bioaccessibility and speciation from four soils were investigated using a modified PBET method (Ruby et al., 1996; Tang et al., 2006) for the gastric and small intestinal phases combined with SHIME for the colon phase. Briefly, soils ( $0.3 \mathrm{~g})$, in triplicate 
were added to polypropylene conical centrifuge tubes $(50 \mathrm{~mL})$ with the gastric and small intestinal solutions $(30 \mathrm{~mL})$ at a soil/solution $(\mathrm{s} / \mathrm{s})$ ratio of $1: 100$. Following the small intestinal phase, we made a comparison of the absence/presence of small intestinal digests in the colon phase. The intestinal digest was removed and the colon solution was added to the residual soils at a ratio (s/s) of 1:100; this was the no intestinal digest-colon phase (NI-colon phase). In the alternate process, these digests were transferred into $100 \mathrm{~mL}$ anaerobic serum bottles with $30 \mathrm{~mL}$ of colon solution from the descending colon compartment of the dynamic SHIME system at a ratio $(s / s)$ of 1:200; this was the colon phase. Subsequently, the bottles were capped with butyl rubber stoppers and immediately flushed with nitrogen gas for $20-30 \mathrm{~min}$ to obtain anaerobic conditions. The digests were shaken at $150 \mathrm{rpm}$ and incubated at $37{ }^{\circ} \mathrm{C}$ for $18 \mathrm{~h}$.

\subsection{Caco-2 cell culture}

The Caco- 2 cell line was purchased from the Institute of Basic Sciences of the Chinese Academy of Medical Sciences School of Basic Medicine of the Peking Union Medical College. A detailed description is consulted in Fu and Cui (2013). In brief, cells (passage number 25-30) were routinely grown in $25 \mathrm{~cm}^{2}$ flasks in Dulbecco's modified Eagle's medium (DMEM, Hyclone, USA) supplemented with $20 \%$ (v/v) fetal bovine serum (FBS, Hyclone), $1 \%(\mathrm{v} / \mathrm{v}$ ) nonessential amino acids (NEAA) and 1\% antibiotics (complete medium). The cell lines were incubated at $37{ }^{\circ} \mathrm{C}, 95 \%$ air and $5 \% \mathrm{CO}_{2}$ in a humidified atmosphere, and the medium was replaced every $2-3 \mathrm{~d}$. When the cell monolayer reached a confluence of approximately $80 \%$, the cells were subcultured with a solution of $0.25 \%$ trypsin-EDTA (ethylene diamine tetraacetic acid). To establish the Caco-2 intestinal model, cells were seeded at a density of $5 \times 10^{4}$ cells $\mathrm{cm}^{2}$ on a transwell plate (Millpore 24-well Millicell Hangcell Culture Insert, $0.4 \mu \mathrm{m}$ pore size membrane, PET; Corning Incorporated, NY, USA). The media was replaced every other day for $21 \mathrm{~d}$ to obtain confluent, differentiated cell monolayers (DhuiqueMayer et al., 2007). The cellular monolayer integrity was checked by measuring trans-epithelial electrical resistance (TEER) with a volt-ohm meter equipped with a chopstick electrode (Millicell ERS2, Millipore, USA).

\subsection{Absorption of As species by Caco-2 cells}

To assess the absorption of bioaccessible As after the colon phase across the gut epithelium, this study was undertaken using standard As aqueous solutions and colon digests by an in vitro Caco2 cell line model. For As absorption through Caco- 2 cells, the colon digests were heated by immersion in a water bath for $5 \mathrm{~min}, 90^{\circ} \mathrm{C}$ to denature enzymes used for digestion, and then filtrated with a $0.2 \mu \mathrm{m}$ Supor membrane (PN 4612, Pall Corporation, MI, USA). The samples were diluted 1:3 with DMEM. The apical side of the cell monolayers received $0.5 \mathrm{~mL}$ of the dilution, and the basolateral side received $0.5 \mathrm{~mL}$ of FBS-free medium. After $4 \mathrm{~h}$ of incubation at $37{ }^{\circ} \mathrm{C}, 5 \% \mathrm{CO}_{2}$, and $95 \%$ relative humidity, the media from the apical chamber was harvested. TEER values $\left(>600 \mathrm{Ohms} \mathrm{cm}^{2}\right.$ ) were measured to control cell monolayer integrity during the experiments.

All samples passed through $0.45 \mu \mathrm{m}$ filter were subsequently stored at $-80{ }^{\circ} \mathrm{C}$ until analysis. The total arsenic was quantified using ICP-MS. Arsenic speciation was determined by highperformance liquid chromatography (HPLC) coupled with ICPMS. Chromatographic columns were obtained from Hamilton and consisted of a pre-column $(11.2 \mathrm{~mm}, 12-20 \mu \mathrm{m})$ and a PRP$\mathrm{X} 10010-\mu \mathrm{m}$ anion-exchange column $(250 \mathrm{~mm} \times 4.1 \mathrm{~mm})$. The standards [As(III), As(V), DMA ${ }^{\mathrm{V}}, \mathrm{MMA}^{\mathrm{V}}$ and $\mathrm{MMMTA}^{\mathrm{V}}$ ] were included as quantified by external calibration curves with peak areas. MMMTA ${ }^{\mathrm{V}}$ was synthesized by this method (Alava et al., 2012; Rubin et al., 2014). The sum of all chromatographic As species detected in the filtrate $(0.45 \mu \mathrm{m})$ of the colon digests was used to determine As bioaccessibility. In addition, the chromatographic recovery was validated previously (Yin et al., 2015; Zhu et al., 2008).

\section{Results and discussion}

\subsection{Arsenic speciation in the colon digests and arsenic release from} soils by human colon microbiota

The As bioaccessibility values in the small intestinal and colon phases were highly variable among four contaminated soils (Table 1 and Table S1). We observed that As bioaccessibility in the colon phase was 1.7-5.8 times that of the small intestinal phase. Significantly, a large amount of soil As (3.7-581.2 $\mathrm{mg} \mathrm{kg}^{-1}$ with mean value $212.0 \mathrm{mg} \mathrm{kg}^{-1}$ ) was released in the colon phase by human gut microbiota (Table 1). Through the control test with the sterile colon solution for soils $1-3$, a certain degree of As dissolution (17.7-146.4 mg kg-1) from soils was observed, while the values were lower than As release in the NI-colon phase. Accordingly, the bioaccessible As concentration in the colon phase was 5.7-664.6 $\mathrm{mg} \mathrm{kg}^{-1}$ with mean value $267.4 \mathrm{mg} \mathrm{kg}^{-1}$ (Fig. S1). Arsenic bioaccessibility in the colon phase $(20.6-36.8 \%)$ was 1.1-2.0 times that of the NI-colon phase. Subsequently, a high degree of transformation by human gut microbiota was observed, including As reduction (7.4-29.9\%), and methylation (0.7-44.8\%). The presence of $\mathrm{DMA}^{\mathrm{V}}, \mathrm{MMA}^{\mathrm{V}}$, and MMMTA ${ }^{\mathrm{V}}$ was detected as methylarsenicals with different extents of As methylation in the colon phase (Table 1). The methylation percentage in soil 4 was higher with $44.8 \%$ and $42.1 \%$, respectively, in the NI-colon and colon digests. The NI-colon and colon digests of soils 1-3 displayed a methylation percentage of $0.7-13.5 \%$ and $3.3-17.4 \%$ respectively. Additionally, a significant amount of As(III) (6.4-105.9 mg kg-1) was observed and inorganic As was predominantly present in the colon phase.

Similar to previous studies, our findings showed that human colon microbiota have the capacity for presystemic As metabolism (Van de Wiele et al., 2010; Yin et al., 2015). Importantly, the difference in the metabolic activity and ability in the absence/presence of the small intestinal digests, illustrated that human gut microbiota gave priority to transform dissolved As. In this study, plenty of $\mathrm{As}(\mathrm{III})$ was observed in the colon digests and soil solid phase. The $\mathrm{As}(\mathrm{V})$ reduction process can directly occur in the solid phase; $\mathrm{As}(\mathrm{V})$ in the digests was reduced to $\mathrm{As}(\mathrm{III})$, and then a part of these As(III) generated was adsorbed onto the soil solid phase. As Zhu et al. (2014) summarized the biotransformation between different As species, $\mathrm{As}(\mathrm{III})$ is primarily methylated into $\mathrm{MMA}^{\mathrm{V}}$, and then the $\mathrm{MMA}^{\mathrm{V}}$ is transformed into $\mathrm{DMA}^{\mathrm{V}}$ during the process of As metabolism. On the other hand, $\mathrm{MMA}^{\mathrm{V}}$ can be an intermediate in the production of MMMTAV (with unknown toxicity) by microbial thiolation; the sulfide source can be $\mathrm{H}_{2} \mathrm{~S}$, which sulfate-reducing bacteria (SBR) from the human gut tract have the ability to produce (Rubin et al., 2014). In addition, $\mathrm{DMA}^{\mathrm{V}}$ can be converted into other methylated thioarsenates, such as trimethylarsine sulfide, in animal gastrointestinal environments (Kubachka et al., 2009; Kuroda et al., 2004). $\mathrm{MMA}^{\mathrm{V}}$ can be reduced to the highly toxic MMA ${ }^{\text {III }}$, which indicates that As methylation will not lead to detoxification (Van de Wiele et al., 2010). Finally, S-adenosylmethionine is known to transfer its methyl group to As(III) (Zhu et al., 2014), but the understanding of methyl group donors is limited. We need to further elucidate the mechanism of As methylation in human gut tract. 
Table 1

Arsenic bioaccessilibity, transformation, and release in the colon phase.

\begin{tabular}{|c|c|c|c|c|c|c|c|c|c|c|c|c|}
\hline \multirow[t]{3}{*}{ Sample } & \multirow[t]{3}{*}{ As bioaccessibility (\%) } & \multicolumn{3}{|c|}{ Soil solid phase ${ }^{a}$} & \multirow{2}{*}{\multicolumn{2}{|c|}{$\begin{array}{l}\text { As } \\
\text { methylation }^{\mathrm{b}}\end{array}$}} & \multicolumn{4}{|c|}{$\mathrm{As}(\mathrm{V})$ reduction ${ }^{\mathrm{c}}$} & \multirow[t]{3}{*}{$\operatorname{As}(\mathrm{V})$ transformation $^{\mathrm{d}}\left(\mathrm{mg} \mathrm{kg}^{-1}\right)$} & \multirow[t]{3}{*}{$\mathrm{As}(\mathrm{V})$ release $^{\mathrm{e}}\left(\mathrm{mg} \mathrm{kg}^{-1}\right)$} \\
\hline & & \multicolumn{2}{|l|}{$\mathrm{As}(\mathrm{III})$} & \multirow{2}{*}{$\frac{\mathrm{As}(\mathrm{V})}{(\%)}$} & & & & & Solid & Aqueous & & \\
\hline & & $\left(\mathrm{mg} \mathrm{kg}^{-1}\right)$ & (\%) & & $\left(\mathrm{mg} \mathrm{kg}^{-1}\right)$ & $(\%)$ & $\left(\mathrm{mg} \mathrm{kg}^{-1}\right)$ & $(\%)$ & $(\%)$ & (\%) & & \\
\hline \multicolumn{13}{|c|}{ In the colon phase In the NI-colon phase (no intestinal digest-colon phase) } \\
\hline Soil 1 & $16.2 \pm 1.2$ & 28.3 & 8.7 & 91.3 & 7.1 & 13.5 & 38.3 & 11.8 & 74.0 & 26.0 & 45.4 & 52.3 \\
\hline Soil 2 & $30.0 \pm 0.2$ & 105.3 & 12.5 & 87.5 & 3.2 & 1.3 & 148.5 & 17.6 & 44.2 & 55.8 & 151.7 & 253.1 \\
\hline Soil 3 & $18.0 \pm 1.7$ & 341.4 & 10.6 & 89.4 & 4.0 & 0.7 & 238.2 & 7.4 & 90.5 & 9.5 & 242.2 & 581.2 \\
\hline Soil 4 & $23.7 \pm 0.1$ & & & & 1.7 & 44.8 & & & & & & 3.7 \\
\hline \multicolumn{13}{|c|}{ In the colon phase } \\
\hline Soil 1 & $32.8 \pm 2.2$ & 36.6 & 11.3 & 88.7 & 18.5 & 17.4 & 43.0 & 13.3 & 85.1 & 14.9 & 61.5 & 66.9 \\
\hline Soil 2 & $34.8 \pm 0.1$ & 185.9 & 22.0 & 78.0 & 15.1 & 5.1 & 252.2 & 29.9 & 58.0 & 42.0 & 267.3 & 183.9 \\
\hline Soil 3 & $20.6 \pm 1.5$ & 391.8 & 12.1 & 87.9 & 21.9 & 3.3 & 272.6 & 8.5 & 97.6 & 2.4 & 294.5 & 549.2 \\
\hline Soil 4 & $36.8 \pm 1.6$ & & & & 2.4 & 42.1 & & & & & & 5.7 \\
\hline
\end{tabular}

a As speciation after the colon phase measured by XANES, and soil 4 with lower As concentration not included.

b Calculated by dividing the sum of $\mathrm{MMA}^{\mathrm{V}}, \mathrm{DMA}^{\mathrm{V}}$, and MMMTA ${ }^{\mathrm{V}}$ by As concentration in the colon digests.

c As(III) concentration and percentage (of total soil As) due to microbial As(V) reduction; the percentage of As(III) generated in the colon digest and the soil solid phase.

d The sum of As methylation and $\mathrm{As}(\mathrm{V})$ reduction.

e Soil $\mathrm{As}(\mathrm{V})$ release in the colon phase excluding As concentration in the small intestinal digests.

\subsection{Arsenic speciation in the soil solid phase and soil As fractions}

The important part of this study consisted of As speciation analysis in the soil solid phase by XANES (Table S2 and Fig. S2). Subsequently, summarizing As speciation changes in the digest and soil solid phase, we comprehensively calculated two important values of $\mathrm{As}(\mathrm{V})$ reduction and $\mathrm{As}(\mathrm{V})$ transformation by human gut microbiota taking into account both the NI-colon and colon phases in soils 1-3 (Table 1, Table S2, and Fig. S1). To keep the reliability and accuracy of data, soil 4 with lower As concentration was not measured. In consideration of both digests and soil solid phases, $\mathrm{As}(\mathrm{III})$ concentrations generated by microbial reduction in the NIcolon phase were $38.3-238.2 \mathrm{mg} \mathrm{kg}^{-1}$, lower than that in the colon phase. Importantly, 44.2-97.6\% of the generated As(III) was attached to the soil solid phase. In comparison to the origin soils exceeding $95 \% \mathrm{As}(\mathrm{V})$, the amount of $\mathrm{As}(\mathrm{III})$ on the soil solid phase of the colon phases increased by $28.3-266.0 \mathrm{mg} \mathrm{kg}^{-1}$. In addition, it is important to note that there is particularly high $\mathrm{As}(\mathrm{V})$ transformation in soil 3, which illustrates that microbial metabolism may have a threshold value. Furthermore, the transformed $\mathrm{As}(\mathrm{V})$ concentrations [which included As(III) due to microbial reduction and organic As by methylation and thiolation] reached $61.5-294.5 \mathrm{mg} \mathrm{kg}^{-1}$, which were higher than corresponding values in the NI-colon phase. The result demonstrated that As in the colon digests was transformed more quickly than that in the soil solid phase. From the concentrations of different As fractions (Table S3), combined with our previous results (Yin et al., 2015), linear correlation analysis showed that there is a significant correlation between soil $\mathrm{As}(\mathrm{V})$ release and transformation in the colon phase (including bioaccessible As in the small intestinal phase) and the sum of soil F1, F2, F3 fractions (slope $=0.53 ; y$-intercept $=91.3$; $r^{2}=0.96 ; n=7 ; P<0.01$ ), as well as the sum of soil F1, F2, F3, and F4 fractions (slope $=0.43 ; y$-intercept $=67.8 ; r^{2}=0.96 ; n=7$; $P<0.01$ ) (Fig. 1). Soil As(V) release and transformation in the NIcolon phase was significantly correlated with the sum of soil F1, F2, F3 fractions $\left(r^{2}=0.97 ; n=3\right.$ ) (Fig. S3). Interestingly, soil 4 with low As concentration, had a certain As release (3.7-5.7 $\mathrm{mg} \mathrm{kg}^{-1}$ ), which illustrated that human gut microbiota can metabolize certain soil As fractions.

The present study demonstrates that human colon microbiota have the potency to release directly soil-bound As, particularly Asbearing amorphous Fe/Al-oxides. Generally, most or all of dissolved iAs as the predominant species from soil As exposure is absorbed in small intestine (Vahter, 1983; Yin et al., 2015). Therefore, significant soil-bound As (the fraction of As that did not release into the small intestine from soils) can end up in the colon with the abundant microbial community. Identifying As speciation and distribution between the digests and soil solid phase of colon phase, we observed soil-bound As release and transformation by human gut microbiota when, hypothetically, all of the As was absorbed in the
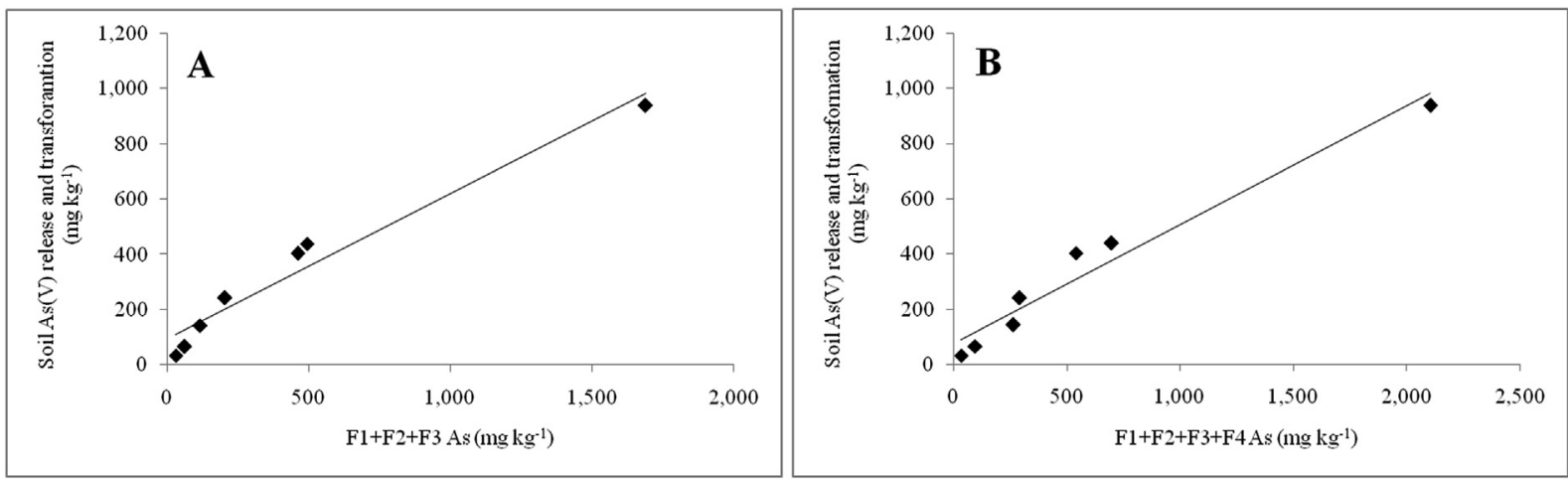

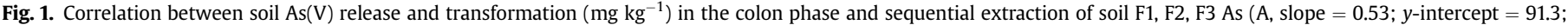

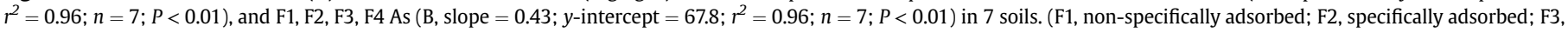
amorphous $\mathrm{Fe}$ and $\mathrm{Al}$ oxides; $\mathrm{F} 4$, crystalline $\mathrm{Fe}$ and $\mathrm{Al}$ oxides). 
small intestine. The important result was soil As release (3.7-581.2 mg $\mathrm{kg}^{-1}$ ) and a certain amount of $\mathrm{As}(\mathrm{III})$ (28.3-215.6 mg kg-1) on the soil solid phase. Accordingly, it once more illustrated the importance of XANES investigation of As speciation in the soil solid phase (Yin et al., 2015). During in vitro experiments, the mobility of As in soils is mainly controlled by adsorption/desorption processes involving metal oxides. It is reported that As mobilization was enhanced by $\mathrm{As}(\mathrm{V})$ reduction from As-bearing minerals in the presence of $\mathrm{As}(\mathrm{V})$-reducing bacteria (Smeaton et al., 2012; Smith et al., 2014). As detailed in Tian et al. (2015) microbial Fe(III) reduction may have two opposite consequences on the fate of associated As mobilization (Cummings et al., 1999; Islam et al., 2004) and sequestration (Coker et al., 2006; Islam et al., 2005; Jiang et al., 2013). In anaerobic environments, the adsorption capacity of As is weaker due to the reductive dissolution of $\mathrm{Fe}$ (III) oxides in the presence of $\mathrm{Fe}(\mathrm{III})$-reducing bacteria; consequently, in the NI-colon phase with dissolved Fe concentrations (Fig. S4), the dissolution of Fe oxides can cause As release from residual soils after the small intestinal phase. However, in the opposite case, the formation of secondary Fe-minerals during Fe(III) reductive dissolution can sequester a number of As. In the colon phase, an increase of As(III) on the soil solid phase can result from the sequestration of secondary Fe-minerals in consideration of lower Fe concentrations compared to that in the small intestinal phase (Fig. S4). Therefore, As mobilization should be the result of concurrent processes including reductive dissolution of $\mathrm{Fe}(\mathrm{III})$ oxides, liberation and biotransformation of $\mathrm{As}(\mathrm{III} / \mathrm{V})$, and sequestration of As on Fe minerals. As mentioned, As(III) oxidation and $\mathrm{As}(\mathrm{V})$ sequestration by Mn oxides can also play a small, but influential role in As speciation and mobilization (Ying et al., 2011).

\subsection{Intestinal absorption of soil As metabolites}

Another important observation was the high degree of intestinal absorption using Caco-2 cells of As metabolites $[\mathrm{As}(\mathrm{V}), \mathrm{As}(\mathrm{III})$, $\mathrm{MMA}^{\mathrm{V}}, \mathrm{DMA}^{\mathrm{V}}$ ] by human colon microbiota from As-contaminated soils. Through exposure to four As standards (Table S4), intestinal absorption of $\mathrm{As}$ (III) (33.7\%) clearly exceeded that of all other As species, and the transport of the pentavalent organoarsenic compounds $\left(\mathrm{MMA}^{\mathrm{V}}\right.$ and $\mathrm{DMA}^{\mathrm{V}}$ ) through the Caco-2 cell monolayer is low (Calatayud et al., 2010; Hinrichsen et al., 2015). For soil As metabolites, the intestinal absorption of different As species was variable (Fig. 2). The absorption of $\mathrm{MMA}^{\mathrm{V}}, \mathrm{DMA}^{\mathrm{V}}, \mathrm{As}(\mathrm{III})$, and $\mathrm{As}(\mathrm{V})$ was $33.6 \%, 25.1 \%, 30.2 \%$, and $21.7 \%$, respectively, and that of total As species from the colon digests reached $27.0 \%$, which was higher than that of the NI-colon digests. Soil 2 had the highest intestinal absorption (49.3\%) of total As metabolites from the colon digests. The inorganic As has a higher absorption concentration than that of $\mathrm{MMA}^{\mathrm{V}}$ and $\mathrm{DMA} \mathrm{V}^{\mathrm{V}}$, which is similar to other studies (Calatayud et al., 2010; Juhasz et al., 2006). Synchronously, the colon digests of soils 1 and 2 displayed a higher absorption of $41.6 \%$ with an additional methylated thioarsenate $\left(M_{M M T A}{ }^{\mathrm{V}}\right)$. Regarding the thiolated As species, MMMTA ${ }^{\mathrm{V}}$ was least concerned. In accordance with previous literature, MMMTA ${ }^{\mathrm{V}}$ with comparatively less toxicity displays a
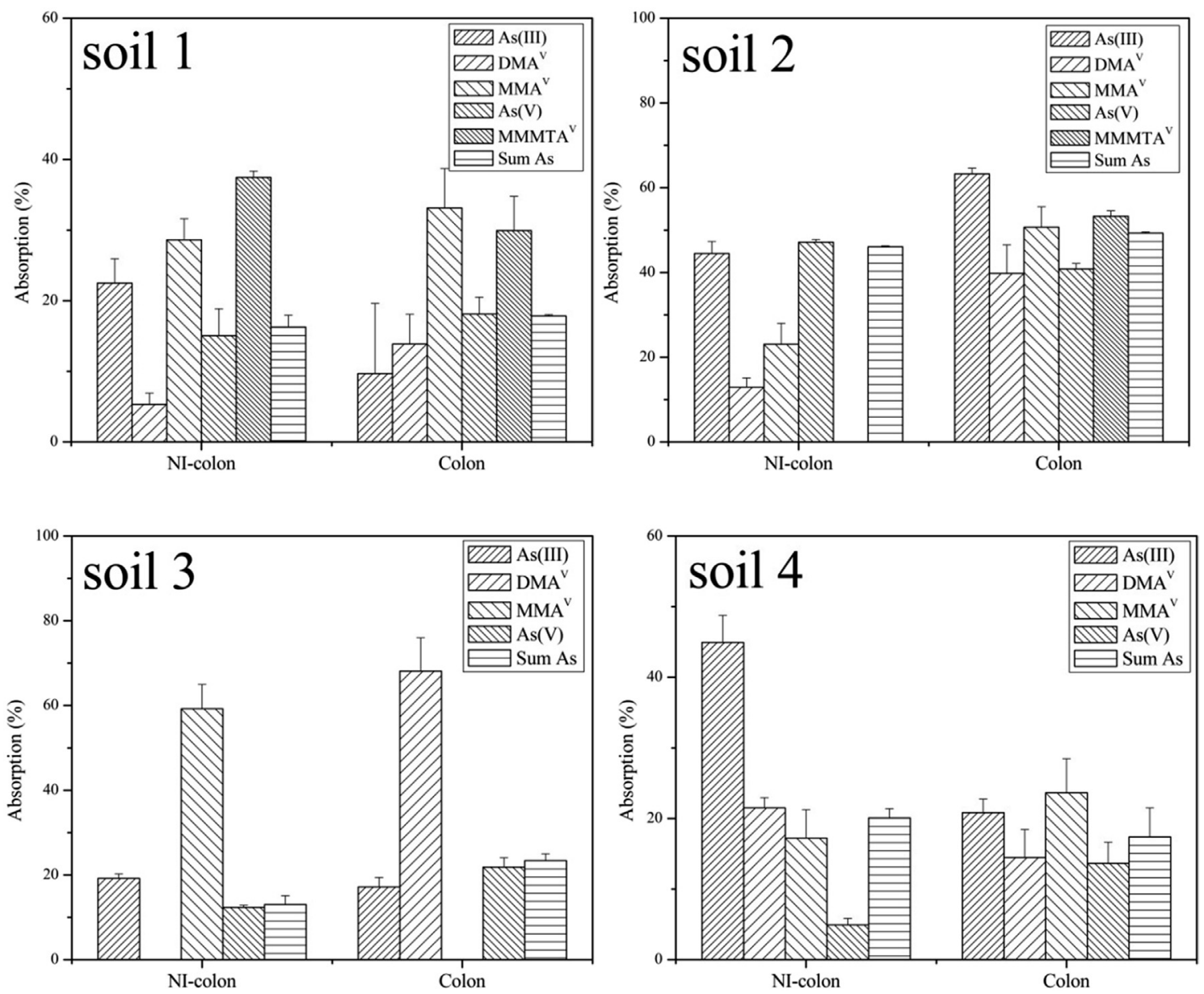

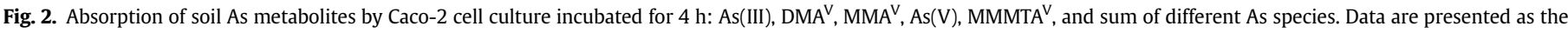
mean \pm standard deviation $(n=3)$. 
high intestinal absorption (Naranmandura et al., 2007b; Hinrichsen et al., 2015). These studies emphasize the necessity for considering As metabolism by human gut microbiota in the colon as a relevant process when assessing As toxicokinetics.

The intestinal absorption of food As metabolites with more methylated arsenicals is notably different (Alava et al., 2015; Laparra et al., 2005a), which can result from the difference in As metabolism by human gut microbiota between foods and soils. The complex soil background (e.g., organic matter, phosphate, and metal ion concentrations) can cause the variability in As absorption, which needs further exploration. The difference in As absorption depended on the various As species, and corresponding transporters, including glucose transporters (GLUT and SGLT), organic anion transporting polypeptides (OATPs), aquaporins (AQPs), and phosphate transporters (NaPi and PiT) (Calatayud et al., 2012a). Hence, in the complex environment from soil As exposure, these comprehensive factors can control the As absorption process. In human intestinal transit, As transformation and intestinal absorption are synchronous. Taking into account As absorption, it needs to be determined whether some As can be redesorbed from the soil solid phase, which can inevitably increase the human health risk. Furthermore, mammalian or human cells including Caco-2 cells have the ability to metabolize iAs or DMA ${ }^{\text {III }}$ (Calatayud et al., 2012b; Naranmandura and Suzuki, 2008). Arsenic transformation concurrently by human colon microbiota and intestinal epithelial cell lines needs be further investigated.

\section{Conclusions}

The present study shows that human gut microbiota has the potency to release a large amount of soil-bound As, particularly Asbearing amorphous $\mathrm{Fe} / \mathrm{Al}$-oxides in the colon phase. The metabolic activity of As in the colon digests by human gut microbiota was faster than that in the soil solid phase. In addition, we are the first to report the different intestinal absorption of soil As metabolites $\left[\mathrm{As}(\mathrm{III}), \mathrm{As}(\mathrm{V})\right.$, methylated arsenicals $\left(\mathrm{MMA}^{\mathrm{V}}\right.$ and $\mathrm{DMA}^{\mathrm{V}}$ ) and thioarsenicals (MMMTA ${ }^{\mathrm{V}}$ )] across the gut epithelium using Caco-2 cells. The complicated background of the soil matrix results in the different absorption between As standards and soil As metabolites. Therefore, (i) the absorption mechanism of different As species under the complex background, and (ii) the toxicity of methylated arsenicals and thioarsenicals need further study. In this context, gut microbial transformation and intestinal absorption must be crucial component to incorporate when predicting bioavailability and evaluating the health risks from oral soil As exposure.

\section{Acknowledgements}

This work was supported by the National Natural Science Foundation of China (No. 41271493). We also thank BSRF for the valuable beamtime.

\section{Appendix A. Supplementary data}

Supplementary data related to this article can be found at http:// dx.doi.org/10.1016/j.chemosphere.2016.10.091

\section{References}

Alava, P., Tack, F., Du Laing, G., Van deWiele, T., 2012. HPLC-ICP-MS method development to monitor arsenic speciation changes by human gut microbiota. Biomed. Chromatogr. 26, 524-533.

Alava, P., Du Laing G. Tack, F., Ryck, T., Van De Wiele, T., 2015. Westernized diet lower arsenic gastrointestinal bioaccessibility but increase microbial arsenic speciation changes in the colon. Chemosphere 119, 757-762.

Bhattacharya, P., Welch, A.H., Stollenwerk, K.G., McLaughlin, M.J., Bundschuh, J.,
Panaullah, G., 2007. Arsenic in the environment: biology and chemistry. Sci. Total Environ. 379, 109-120.

Bradham, K.D., Scheckel, K.G., Nelson, C.M., Seales, P.E., Lee, G.E., Hughes, M.F. Miller, B.W., Yeow, A., Gilmore, T., Serda, S.M., Harper, S., Thomas, D.J., 2011. Relative bioavailability and bioaccessibility and speciation of arsenic in contaminated soils. Environ. Health Perspect. 119, 1629-1634.

Calatayud, M., Gimeno, J., Vélez, D., Devesa, V., Montoro, R., 2010. Characterization of the intestinal absorption of arsenate, monomethylarsonic acid, and dimethylarsinic acid using the Caco-2 cell line. Chem. Res. Toxicol. 23, 547-556.

Calatayud, M., Barrios, J.A., Vélez, D., Devesa, V., 2012a. In vitro study of transporters involved in intestinal absorption of inorganic arsenic. Chem. Res. Toxicol. 25, $446-453$.

Calatayud, M., Velez, D. Devesa, V.,2012b, Metabolism of inorganic arsenic in intestinal epithelial cell lines. Chem. Res. Toxicol. 25, 2402-2411.

Calatayud, M., Vazquez, M., Devesa, V., Velez, D., 2012c. In vitro study of intestinal transport of inorganic and methylated arsenic species by Caco-2/HT29-MTX cocultures. Chem. Res. Toxicol. 25, 2654-2662.

Coker, V.S., Gault, A.G., Pearce, C.I., Van der Laan, G., Telling, N.D., Charnock, J.M., Polya, D.A., Lloyd, J.R., 2006. XAS and XMCD evidence for species-dependent partitioning of arsenic during microbial reduction of ferrihydrite to magnetite. Environ. Sci. Technol. 40, 7745-7750.

Cummings, D.E., Caccavo, F., Fendorf, S., Rosenzweig, R.F., 1999. Arsenic mobilization by the dissimilatory Fe(III)-reducing bacterium Shewanella alga BrY. Environ. Sci. Technol. 33, 723-729.

Dhuique-Mayer, C., Borel, P., Reboul, E., Caporiccio, B., Besancon, P., Amiot, M.J., 2007. B-Cryptoxanthin from Citrus juices: assessment of bioaccessibility using an in vitro digestion/Caco-2 cell culture model. Br. J. Nutr. 97, 883-890.

Ekmekcioglu, C., 2002. A physiological approach for preparing and conducting intestinal bioavailability studies using experimental systems. Food Chem. 76, $225-230$

Fu, J., Cui, Y.S., 2013. In vitro digestion/Caco-2 cell model to estimate cadmium and lead bioaccessibility/bioavailability in two vegetables: the influence of cooking and additives. Food Chem. Toxicol. 59, 215-221.

Hinrichsen, S., Geist, F., Planer-Friedrich, B., 2015. Inorganic and methylated thioarsenates pass the gastrointestinal barrier. Chem. Res. Toxicol. 28, 1678-1680.

Islam, F.S., Gault, A.G., Boothman, C., Polya, D.A., Charnock, J.M., Chatterjee, D., Lloyd, J.R., 2004. Role of metal-reducing bacteria in arsenic release from Bengal delta sediments. Nature 430, 68-71.

Islam, F.S., Pederick, R.L., Gault, A.G., Adams, L.K., Polya, D.A., Charnock, J.M., Lloyd, J.R., 2005. Interactions between the Fe(III)-reducing bacterium Geobacter sulfurreducens and arsenate, and capture of the metalloid by biogenic Fe(II). Appl. Environ. Microbiol. 71, 8642-8648.

Jiang, S., Lee, J.H., Kim, D., Kanaly, R.A., Kim, M.G., Hur, H.G., 2013. Differential arsenic mobilization from As-bearing ferrihydrite by iron-respiring Shewanella strains with different arsenic-reducing activities. Environ. Sci. Technol. 47, 8616-8623.

Juhasz, A.L., Smith, E., Weber, J., Rees, M., Rofe, A., Kuche, L.T., Sansom, L., Naidu, R., 2006. In vivo assessment of arsenic bioavailability in rice and its significance for human health risk assessment. Environ. Health Perspect. 114, 1826-1831.

Kelly, M.E., Brauning, S., Schoof, R., Ruby, M.V., 2002. Assessing Oral Bioavailability of Metals in Soils. Battelle Press, Columbus, OH.

Kim, E.J., Yoo, J.C., Baek, K., 2014. Arsenic speciation and bioaccessibility in arseniccontaminated soils: sequential extraction and mineralogical investigation. Environ. Pollut. 186, 29-35.

Kubachka, K.M., Kohan, M.C., Herbin-Davis, K., Creed, J.T., Thomas, DJ., 2009. Exploring the in vitro formation of trimethylarsine sulfide from dimethylthioarsinic acid in anaerobic microflora of mouse cecum using HPLC-ICP-MS and HPLC-ESI-MS. Toxicol. Appl. Pharmacol. 239, 137-143.

Kuroda, K., Yoshida, K., Yoshimura, M., Endo, Y., Wanibuchi, H., Fukushima, S., Endo, G., 2004. Microbial metabolite of dimethylarsinic acid is highly toxic and genotoxic. Toxicol. Appl. Pharmacol. 198, 345-353.

Laparra, J.M., Velez, D., Barbera, R., Farre, R., Montoro, R., 2005a. Bioavailability of inorganic arsenic in cooked rice: practical aspects for human health risk assessments. J. Agric. Food Chem. 53, 8829-8833.

Laparra, J.M., Velez, D., Barbera, R., Montoro, R., Farre, R., 2005b. An approach to As(III) and As(V) bioavailability studies with Caco-2 cells. Toxicol. In Vitro 19, 1071-1078.

Ljung, K., Selinus, O., Otabbong, E., Berglund, M., 2006. Metal and arsenic distribution in soil particle sizes relevant to soil ingestion by children. Appl. Geochem. 21, 1613-1624.

Molly, K., Vandewoestyne, M., Desmet, I., Verstraete, W., 1994. Validation of the simulator of the human intestinal microbial ecosystem (SHIME) reactor using microorganism-associated activities. Microb. Ecol. Health Dis. 7, 191-200.

Moreda-Pineiro, J., Moreda-Pineiro, A., Romaris-Hortas, V., Moscoso-Perez, C., Lopez-Mahia, P., Muniategui-Lorenzo, S., Bermejo-Barrera, P., PradaRodriguez, D., 2011. In-vivo and in-vitro testing to assess the bioaccessibility and the bioavailability of arsenic, selenium and mercury species in food samples. Trac-Trend Anal. Chem. 30, 324-345.

Naranmandura, H., Suzuki, K.T., 2008. Formation of dimethylthioarsenicals in red blood cells. Toxicol. Appl. Pharmacol. 227, 390-399.

Naranmandura, H., Suzuki, N., Iwata, K., Hirano, S., Suzuki, K.T., 2007a. Arsenic metabolism and thioarsenicals in hamsters and rats. Chem. Res. Toxicol. 20, 616-624.

Naranmandura, H., Ibata, K., Suzuki, K.T., 2007b. Toxicity of dimethylmonothioarsinic acid toward human epidermoid carcinoma A431 cells. Chem. Res. 
Toxicol. 20, 1120-1125.

Rubin, S.S.C.D., Alava, P., Zekker, I., Du Laing, G., Van de Wiele, T., 2014. Arsenic thiolation and the role of sulfate-reducing bacteria from the human intestinal tract. Environ. Health Perspect. 122, 817-822.

Ruby, M.V., Davis, A., Schoof, R., 1996. Estimation of lead and arsenic bioavailability using a physiologically based extraction test. Environ. Sci. Technol. 30, 422-430.

Smeaton, C.M., Walshe, G.E., Smith, A.M.L., Hudson-Edwards, K.A., Dubbin, W.E., Wright, K., Beale, A.M., Fryer, B.J., Weisener, C.G., 2012. Simultaneous release of $\mathrm{Fe}$ and as during the reductive dissolution of $\mathrm{Pb}-\mathrm{As}$ jarosite by Shewanella putrefaciens CN32. Environ. Sci. Technol. 46, 12823-12831.

Smith, E., Scheckel, K., Miller, B.W., Weber, J., Juhasz, A.L., 2014. Influence of in vitro assay $\mathrm{pH}$ and extractant composition on as bioaccessibility in contaminated soils. Sci. Total Environ. 473, 171-177.

Sun, G.X., Van de Wiele, T., Alava, P., Tack, F., Du Laing, G., 2012. Arsenic in cooked rice: effect of chemical, enzymatic and microbial processes on bioaccessibility and speciation in the human gastrointestinal tract. Environ. Pollut. 162, $241-246$.

Tang, X.Y., Zhu, Y.G., Cui, Y.S., Duan, J., Tang, L., 2006. The effect of ageing on the bioaccessibility and fractionation of cadmium in some typical soils of China. Environ. Int. 32, 682-689.

Tian, H.X., Shi, Q.T., Jing, C.Y., 2015. Arsenic biotransformation in solid waste residue: comparison of contributions from bacteria with arsenate and iron reducing pathways. Environ. Sci. Technol. 49, 2140-2146.
Vahter, M., 1983. Metabolism of arsenic: biological and environmental effects of arsenic. In: Fowler, B.A. (Ed.), Biological Effect of Arsenic. Elsevier Science, Amsterdam, pp. 171-197.

Van de Wiele, T., Gallawa, C.M., Kubachka, K.M., Creed, J.T., Basta, N., Dayton, E.A. Whitacre, S., Du Laing, G., Bradham, K., 2010. Arsenic metabolism by human gut microbiota upon in vitro digestion of contaminated soils. Environ. Health Perspect. 118, 1004-1009.

Yin, N.Y., Zhang, Z.N., Cai, X.L., Du, H.L., Sun, G.X., Cui, Y.S., 2015. An in vitro method to assess soil arsenic metabolism by human gut microbiota: arsenic speciation and distribution. Environ. Sci. Technol. 49, 10675-10681.

Yin, N.Y., Du, H.L., Zhang, Z.N., Cai, X.L., Li, Z.J., Sun, G.X., Cui, Y.S., 2016. Variability of arsenic bioaccessibility and metabolism in soils by human gut microbiota using different in vitro methods combined with SHIME. Sci. Total Environ. 566, $1670-1677$.

Ying, S.C., Kocar, B.D., Griffis, S.D., Fendorf, S., 2011. Competitive microbially and Mn oxide mediated redox processes controlling arsenic speciation and partitioning. Environ. Sci. Technol. 45, 5572-5579.

Zhu, Y.G., Sun, G.X., Lei, M., Teng, M., Liu, Y.X., Chen, N.C., Wang, L.H., Carey, A.M. Deacon, C., Raab, A., Meharg, A.A., Williams, P.N., 2008. High percentage inorganic arsenic content of mining impacted and nonimpacted Chinese rice. Environ. Sci. Technol. 42, 5008-5013.

Zhu, Y.G., Yoshinaga, M., Zhao, F.J., Rosen, B.P., 2014. Earth abides arsenic biotransformations. Ann. Rev. Earth Pl. Sci. 42, 443-467. 